\title{
FAULTY ANALYSIS IN EASEMENT AND LICENSE CASES
}

\author{
WESLEY NEWCOMB HOHFELD
}

Professor of Law, Yale University

A recent Pennsylvania case, Penman v. Jones, ${ }^{1}$ involving important coal mining interests, suggests not only some brief observations on what appears to be a novel decision as to easements, but also some critical comments on that which is of far greater significance: the reasoning by which the result was reached. ${ }^{2}$

The unusual chaos of conceptions and inadequacy of reasoning in easement and license cases have not infrequently been emphasized-without, however, any suggestion either as to the cause of the difficulties involved or as to the remedy to be applied. Thus, a learned New Jersey judge, Vice-Chancellor Van Fleet, has put the matter in terms none too strong : ${ }^{3}$

"The adjudications upon this subject [easements and licenses] are numerous and discordant. Taken in their aggregate, they cannot be reconciled, and if an attempt should be made to arrange them into harmonious groups, I think some of them would be found to be so eccentric in their application of legal principles, as well as in their logical deductions, as to be impossible of classification."

The difficulties so justly lamented by the New Jersey court find striking exemplification when one ponders and compares the majority opinion and the dissenting opinion in Penman $v$. Jones. ${ }^{5}$ It is believed, moreover, that a close examination of this case and others may suggest both cause and remedy.

In 1873, A (Lackawanna Iron \& Coal Co.), the owner of a certain large tract of land, sold and conveyed a part of it to B, excepting and reserving to the grantor, its "successors and

2 (I917, Pa.) I00 Atl. 1043.

2 Similarly interesting for its reasoning and for its application of fundamental legal conceptions is the comparatively recent case of Graff Furnace Co. v. Scranton Coal Co. (I914) 244 Pa. 592, 598.

East Jersey Iron Co. v. Wright (I880) 32 N. J. Eq. 248, 254. The italics in the passage quoted from this case and also in the passages to be hereafter quoted from other cases are those of the present writer.

- Compare Chancellor Kent's remarks on the same subject, 3 Kent, Com. *453.

(rg17, Pa.) 100 Atl. 1043. 
assigns," the underlying mineral estate, in apt words creating a fee therein, together "with the sole right and privilege to mine and remove the same [coal and minerals] by any subterranean process incident to the business of mining, without thereby incurring, in any event whatever, any liability for injury caused or damage done to the surface of said lot."

Eighteen years after this, that is in I89I, A, by a single instrument sold and conveyed to C (Lackawanna Iron \& Steel Co.) all the coal under its lands; that is, created subjacent estates in fee, the superjacent estates being, by exception, vested in the grantor. ${ }^{\circ}$ Included in the deed of conveyance, conveying all told about sixty-two parcels, was the subjacent mineral estate below B's lot. While this deed conferred, comprehensively, the "right" to "mine and remove the said coal" from the sixty-two parcels, the right and privilege of letting down the surface were given in specific terms only as regards a single tract not directly connected with B's lot.

On the other hand, as regards all the parcels included, the instrument purported to convey "all the estate, right, title, interest, benefit, property, claim, and demand whatsoever" together with "all and singular the . . a appurtenances . . . belonging to the said . . property or in any wise appertaining to the same."

Twenty-four years later $A$ executed a deed to $D$, a trust company, for "all and every the real estate or interest of any kind or nature" in certain land including, inter alia, the lot previously sold to B and "the coal and minerals underlying the same." Subsequently $D$ quitclaimed to $E$ (who had derived title from $B$ ),

"The superjacent estate, though often spoken of as "remaining," after severance, in the grantor, is really, of course, a somewhat modified legal interest, that is an aggregate of rights, privileges, powers and immunities relating to the smaller corpus of land and having somewhat different elements or characteristics than the aggregate relating to the larger corpus originally "owned."

For this reason the usual language of the books is hardly adeguate,e. g., Tiffany, Real Property (1903) sec. 383:

"The purpose and effect of an exception in a conveyance is to except or exclude from the operation of the conveyance some part of the thing or things covered by the general words of description therein, as when one conveys a piece of land, excepting a certain part thereof, or the houses thereon, it being always of a thing actually existent. A reservation, on the contrary, as defined by the common-law writers, is a clause by which the grantor reserves to himself some new thing 'issuing out of' the thing granted, and not in esse before." 
with the express purpose of investing $E$ of the right of surface support against the owner of the subjacent estate.

In a suit by $E$ against $F$ for breach of a contract to purchase the surface lot, it was held by the Supreme Court of Pennsylvania, Moschzisker and Stewart, JJ., dissenting, that the "right and privilege" of letting down the surface of B's lot did not pass from $A$ to $C$ by the conveyance of $I 89 \mathrm{r}$; that such "right and privilege" did pass by the later conveyance to $D$; and that by the latter's quitclaim deed the "right and privilege" were released and extinguished in favor of $E$, so as to make $E$ 's interest perfect as regards the right of surface support.

There are thus presented three questions: (I) Under the conveyance of r8gr, did the "right and privilege" of letting down the surface of B's lot pass to $C$ as an easement appurtenant to the subjacent mineral estate? (2) Did such "right and privilege" pass, under the language of the conveyance, independently of its being an easement? (3) Was the court consistent in holding, in spite of its negative answer to the second question, that the language in the conveyance from $A$ to $D$ was sufficient to pass the "right and privilege" to D? Each of these points may, for the sake of clearness, be somewhat separately considered.

(I) DID THE "RIGHT AND PRIVILEGE" PASS AS AN EASEMENT?

All legal interests concerning land or other tangible objects ${ }^{\tau}$ may, on adequate analysis, be seen to consist of more or less comprehensive aggregates of rights (or claims), privileges,

'As regards the unfortunate tendency to blend and confuse non-legal (physical) and legal conceptions, especially in the use of the term "property" with rapid shifts to indicate both the physical object and the legal interest relating to it, see the detailed discussion in the writer's article, Fundamental Legal Conceptions as Applied in Iudicial Reasoning (19r3) 23 Yale LaW Journal, I6, 20 seq.

Compare also (I9I7) 26 YALE LAW JoURNAL, 710, 721 :

"A man may indeed sustain close and beneficial physical relations to a given physical thing: he may physically control and use such thing, and he may physically exclude others from any similar control or enjoyment. But, obviously, such purely physical relations could as well exist quite apart from, or occasionally in spite of, the law of organized society: physical relations are wholly distinct from jural relations. The latter take significance from the law; and, since the purpose of the law is to regulate the conduct of human beings, all jural relations must, in order to be clear and direct in their meaning, be predicated of such human beings. The words of able judges may be quoted as showing their realization of the practical importance of the point now being emphasized: Mr. Chief Justice Holmes, in Tyler $v$. Court of Registration (I900) I75 Mass. 71, 76: 'All proceedings, like all rights, are really against persons. Whether they are proceedings or rights in rem depends on the number of persons affected." 
powers, and immunities vested in the "owner" of the interest, other persons indiscriminately being under the respective correlative duties, no-rights, liabilities, and disabilities. ${ }^{8}$ The

- See Fundamental Legal Conceptions as Applied in Judicial Reasoning (I9I7) 26 YaLe LAW JouRNad, 7I0, 746:

"Suppose, for example, that A is fee-simple owner of Blackacre. His 'legal interest' or 'property' relating to the tangible object that we call land consists of a complex aggregate of rights (or claims), privileges, powers, and immunities. First: A has multital legal rights, or claims, that others, respectively, shall not enter on the land, that they shall not cause physical harm to the land, etc., such others being under respective correlative legal duties. Second: A has an indefinite number of legal privileges of entering on the land, using the land, harming the land, etc., that is, within limits fixed by law on grounds of social and economic policy, he has privileges of doing on or to the land what he pleases; and correlative to all such legal privileges are the respective legal no-rights of other persons. Third: A has the legal power to alienate his legal interest to another, i. e., to extinguish his complex aggregate of jural relations and create a new and similar aggregate in the other person; also the legal power to create a life estate in another and concurrently to create a reversion in himself; also the legal power to create a privilege of entrance in any other person by giving 'leave and license'; and so on indefinitely. Correlative to all such legal powers are the legal liabilities in other persons, - this meaning that the latter are subject, nolens volens, to the changes of jural relations involved in the exercise of A's powers. Fourth: $A$ has an indefinite number of legal immunities, using the term immunity in the very specific sense of non-liability or non-subjection to a power on the part of another person. Thus he has the immunity that no ordinary person can alienate A's legal interest or aggregate of jural relations to another person; the immunity that no ordinary person can extinguish A's own privileges of using the land; the immunity that no ordinary person can extinguish $A$ 's right that another person $X$ shall not enter on the land or, in other words, create in X a privilege of entering on the land. Correlative to all these immunities are the respective legal disabilities of other persons in general.

"In short, $A$ has vested in himself, as regards Blackacre, multital, or in rem, 'right-duty' relations, multital, or in rem, 'privilege-no-right' relations, multital, or in rem, 'power-liability' relations, and multital, or in rem, 'immunity-disability' relations. It is important in order to have an adequate analytical view of property, to see all these various elements in the aggregate. It is equally important, for many reasons, that the different classes of jural relations should not be loosely confused with one another. A's privileges, e. g., are strikingly independent of his rights or claims against any given person, and either might exist without the other. Thus A might, for $\$ 100$ paid to him by $B$, agree in writing to keep off Blackacre. A would still have his rights or claims against B, that the latter should keep off, etc.; yet, as against B, A's own privileges of entering on Blackacre would be gone. On the other hand, with regard to $X$ 's land, Whiteacre, $A$ has, as against $B$, the privilege of entering thereon; but, not having possession, he has no right, or claim, that B shall not enter on Whiteacre."

For a more detailed analysis, explanation, and discrimination of the fundamental jural relations, see the earlier article, Fundamental Legal Conceptions as Applied in Judicial Reasoning (19r3) 23 YaLE LAW JOURNAL, 16.

As there indicated, p. 4I, the best synonym for "legal privilege," in the very specific sense of "no-duty," is "legal liberty." 
aggregate of the easement owner differs from that of the ordinary complete owner of land only in being far more limited as regards the number and the quality of the constituent jural relations involved. For this reason it is a serious obstacle to close analysis and clear thinking that courts and writers habitually deal with the easement (as they do also with all other legal interests) as if it were a simple unity to be adequately described by a few loose and ambiguous terms such as "property," "title," "ownership," "right of ownership," "right," "privilege," "incorporeal(!) right," etc.-terms utterly insufficient to indicate the precise elements involved. - In none of the books has any strict analytical method been pursued. Some typical "definitions" disclose at a glance how hopelessly inadequate they are to indicate the varieties of jural relations actually included in each of the various kinds of easements. ${ }^{\circ}$ The unfortunate fallacy consists in treating as if it were a solid, unanalyzable unity that which

\section{'Jones, Easements (1898) sec. I :}

"An easement is a privilege without profit which one has for the benefit of his land in the land of another."

Tiffany, Real Property (1903) 677:

"An easement is a right, in one person, created by grant or its equivalent, to do certain acts on another's land, or to compel such other to refrain from doing certain acts thereon, the right generally existing as an accessory to the ownership of neighboring land, and for its benefit."

Mr. Justice Thompson, in Big Mountain Improvement Co.'s Appeal (1867) 54 Pa. 36r, 369:

"This was but the grant of an easement although described to be in fee, which is generally defined to be 'a liberty, privilege or advantage which one may have in the lands of another without profit:' Gale \& Whately on Easements 6."

The usual definitions and explanations of "profits" and other "incorporeal" hereditaments are similarly deficient and unsatisfactory. Compare, e. g., Tiffany, Real Property (I903) 678:

"An easement is to be distinguished from a profit a prendre, which signifies a right in a person to take a part of the soil belonging to another person, or something growing or subsisting on or in the soil."

The most significant and distinguishing elements in the entire aggregate of the "profit" owner are those which the books constantly fail to point out, viz., the legal powers of acquiring ownership of severed parts of the "servient" land by exercising the legal privileges of making physical severance. Of course, rights (or claims) and immunities, as well as privileges and powers, constitute elements in the profit owner's "aggregate." See post pp. 97 seq. 
is really a complex aggregate of many distinct jural relations, actual and potential. ${ }^{10}$

Consider, for example, a right of way over Y's land Whiteacre, the "servient" tenement, $X$ being the owner of Blackacre, the "dominant" tenement. Without attempting an exhaustive analysis of this interest, it is clear that the most significant jural relations included in X's complex aggregate are as follows: First, $X$ has rights, or claims, against others, $-Y$ and third parties, that they shall not interfere with his crossing of Whiteacre, as $e$. $g$., by erecting an obstruction;:11 and all such other persons are under respective correlative duties not to interfere, etc. Second, the most striking jural relations in X's complex aggregate consist of his legal privileges of crossing Whiteacre in various ways (as by walking, riding or driving); $i$. $e_{\text {., }}$, his privilege in any such case is the negation of the duty to stay off which $\mathrm{X}$ would be under were it not for the special easement facts distinguishing him from other individuals. Correlative to $X$ 's privileges are the no-rights of $Y$; i. e., $Y$ has no rights that $X$ should stay off. Though, unfortunately, the point is generally overlooked, and sometimes, in effect, denied, ${ }^{12}$ these "privilege-no-right" relations are as true jural relations as the "right-duty" relations already referred to. ${ }^{13}$ Moreover, it is

${ }^{10}$ The same tendency is manifest in the usual attempts to analyze even the most complex and intricate kinds of jural interests, such as equitable trust interests, corporate ownership, etc. Compare as regards trusts, Fundamental Legal Conceptions as Applied in Judicial Reasoning (I913) 23 Yale LAW JouRNal, I6-I9; The Relations between Equity and Law (IgI3) II MICH. L. Rev. 537, 553; The Conflict of Equity and Law (I917) 26 YALE LAW JoURNAL, 767-770; and, as regards the analysis of corporate ownership, The Nature of Stockholders' Individual Liability for Corporation Debts (1909) 9 CoL. L. REv. 285, 287 seq.; The Individual Liability of Stockholders and the Conflict of Laws (Igro) to CoL. L. REv. 283, 296-326.

11 These are, of course, multital rights (so-called rights in rem), as contrasted with paucital rights (so-called rights in personam).

For an extended analysis and explanation of these conceptions and terms-so often misunderstood-see Fundamental Legal Conceptions as Applied in Judicial Reasoning (I917) 26 YALE LAW JouRNAL, 7IO.

For an explanation of the terms, jus in re and jus in re aliena, see Ibid., 734 seq.

${ }^{2}$ See Pollock, Jurisprudence (2d ed., r904) 62; and cf. Del Vecchio, Formal Bases of Law (tr. by Lisle, 1914) 166-I82.

${ }^{18}$ See Fundamental Legal Conceptions as Applied in Judicial Reasoning (r913) 23 YaLE LAW JoURNAL, 16, 42, n. 59, criticising, inter alia, the views expressed in Pollock, Jurisprudence (2d ed., 1904) 62.

See also ante, p. 69, n. 8. 
the privilege elements in X's interest, involving an affirmative activity on Y's land, Whiteacre, that cause his easement to be classified as affirmative, in contrast to a negative easement, such as that of light. Third, $\mathrm{X}$ has various legal powers: e. g., the power, subject to certain limitations, to create in others, e. g., servants and guests, respective privileges of crossing Whiteacre; the power to alienate his aggregate of relations by conveying it, along with his main Blackacre interest, to $M$-such alienation really consisting of the extinguishment of $X$ 's own relations and the creation of new and corresponding relations in $M ; ;^{14}$ and the power to extinguish his aggregate of relations in favor of $\mathrm{Y}$, leaving no-rights (or no-claims), duties, liabilities and disabilities in place of his previous interest, together with a corresponding transformation of jural relations as regards $Y$ and all third persons. Fourth, $\mathrm{X}$ has various legal immunities, the term "immunity" being here used in the very definite sense of non-liability or non-subjection to legal power on the part of another person. Thus, e. g., $\mathrm{X}$ is free from the power of any person, under ordinary conditions, to extinguish his easement interest.

Passing from affirmative easements to those classified as negative, the typical case is the easement of light. In that case the aggregate consists of rights, or claims, powers and immunities; the significant thing being the absence of privileges to be exercised by $\mathrm{X}$ through affirmative acts on Y's land. ${ }^{15}$

Coming nearer to the problem of the principal case, let us consider two adjacent parcels, Brownacre, owned by $\mathrm{J}$, and Greenacre, owned by $\mathrm{K}$. In the absence of special facts operating in favor of $\mathrm{J}$ or others, $\mathrm{K}$ has so-called "natural rights" to lateral support; $i$. e., such rights, or claims, exist as ordinary elements of K's aggregate of jural relations called "ownership

1 As regards the "alienation" of "legal interests," see the article already cited (I9I3) 23 Yale Law Journal, 16, 24, 45; also Professor Walter W. Cook, The Alienability of Choses in Action (1916) 29 HARv. L. REv. 8I6837; The Alienability of Choses in Action-A Reply to Professor Williston (IgI7) 30 HaRv. L. REv. 449-485.

${ }^{25}$ Compare Holmes, in 3 Kent, Com. *4Ig, note (c):

"In general it is supposed that the duty of the servient owner is the same as that of third persons in point of law, viz., to abstain from interfering with a right in rem, although it is more onerous in point of fact, by reason of his occupation of the land. See D. 43. 19. 3, sec. 5; Saxby v. Manchester, Sheffield, \&. $c_{;}, R$. Co., L. R. 4 C. P. I98. But see Lawence v. Jenkins, L. R. 8 Q. B. 274 ." 
of Greenacre,"-being in no way dependent on special grant or equivalent operative facts, such as reservation or prescription. That is to say, K's right that J shall not, by removing the lateral support, cause K's land to collapse is exactly of the same general character as K's ordinary right that J, having no "right of way" easement or other basis of privilege, shall not walk across Greenacre.

Suppose, however, that $\mathrm{K}$ should, by instrument of grant under seal, purport to create in $\mathrm{J}$, his heirs and assigns, the "right and privilege," of causing, through removal of support, the collapse of $\mathrm{K}$ 's land. Is there any reason why the aggregate of relations so created should not be considered an "easement," and thus involve the application of the usual rules as to the alienation of easements, that is, that easements appurtenant pass ordinarily with the dominant estate even without express mention, ${ }^{16}$ and, a fortiori, under a clause as to "appurtenances?" How, if at all, does J's aggregate of jural relations concerning and affecting Greenacre differ from X's aggregate of jural relations called "right of way" over Whiteacre?

In the Greenacre case, as in the Whiteacre case, we can easily discover right (claim) elements, privilege elements, power elements and immunity elements. The privilege is that of causing the collapse of $K$ 's land through removal of his own soil and concomitant change in the operation of natural forces on $\mathrm{K}$ 's land. The privilege is limited, as indicated, to causing collapse in a particular mode, viz., through change in the operation of natural forces through removal of J's own soil. The power elements and immunity elements are equally obvious. Similarly, there seem to be rights, or claims, corresponding to those involved in X's right of way over Whiteacre. That is, since by the very terms of the supposed grant to $\mathrm{J}, \mathrm{K}$ has given him the "right and privilege"17 of removing lateral support, etc., the intentions of the parties are clear: $J$ has rights against $K$ (and, by analogy to a right of way, against third parties indiscriminately) that they shall not interfere with the "exercise" of J's privilege, that is with the physical activity bringing about a change in natural forces against $K$ 's land. Such an aggregate of jural

${ }^{15}$ See Jones, Easements (I898), sec. 22, collecting the authorities at large.

${ }^{17}$ In Pemman v. Jones ( $1917, \mathrm{~Pa}$.) 100 Atl. I043, it will be remembered, the same terms, "right and privilege," were used in the deed from A to B. 
relations in $\mathrm{J}$ would thus seem to constitute an easement; and authority is not wanting for this view. ${ }^{18}$

A precisely similar analysis is applicable to the operative facts and resulting jural relations involved in Penman $v$. Jones, ${ }^{19}$ the Pennsylvania case chiefly in view. By revolving Greenacre and Brownacre ninety degrees on an axis, the former would become the superjacent estate of $B$, and the latter would become the subjacent estate of A (Lackawanna Iron \& Coal Co.)

It is well settled in Pennsylvania, in accord with the authorities at large, that on the original creation of a subjacent mineral estate, either by grant or by exception, the owner of the superjacent estate acquires an ordinary, or "natural," right of surface support corresponding to the right of lateral support already considered. ${ }^{20}$

Thus in one of the latest cases on the subject, Youghiogheny River Coal Co.v. Allegheny National Bank, ${ }^{21}$ the Supreme Court of Pennsylvania said, by Mr. Justice Mestrezat:

${ }^{13}$ See Ryckman v. Gillis (1874) 57 N. Y. 68, 74. In this case Johnson, C., who dissented only on other grounds, said, at p. 78 :

"But if the right to have support from adjoining land be not an easement, then what may be called the antagonistic right of removing your own soil so as to diminish the support to which the adjoining owner was entitled, is an easement affecting his land in favor of yours, and making his land the servient tenement in that regard, and subject to the easement of being deprived of its natural support. That such an easement may be acquired by grant or agreement of the parties is obvious, and has been settled by repeated adjudications between surface owners and mine owners underneath."

See also, to similar effect, Tiffany, Real Prop. (rg03) 6go. Cf. Jones, Easements (1898) sec. 589 .

Compare also the easement of causing noises and vibrations harmful to the owner of neighboring land. Sturges v. Bridgman (1878) II Ch. D. 852.

${ }^{10}$ (I9I7, Pa.) 100 Atl. 104.

${ }^{20}$ Jones v. Wagner (1870) $66 \mathrm{~Pa} .429,434 ;$ Horner v. Watson (1875) $79 \mathrm{~Pa}$. 242, 25I; Coleman v. Chadwick (1875) 80 Pa. 8I; Williams v. Hay (1888) 120 Pa. 485, 496; Robertson v. Youghiogheny River Coal Co. (I896) I72 Pa. 566, 57 I.

The same principle is recognized and discussed in many of the later Pennsylvania cases cited in the footnotes following.

The leading English case for the same doctrine is Humphries v. Brogden (1850) 12 Q. B. 739. See also the careful discussion in Howley Park Coal \&. Cannel Co. v. London \& N.W. Ry. Co. [1913] A. C. II, 25, per Viscount Haldane, L. C.

For the similar American cases at large, see Tiffany, Real Property (I903) 672, n. 74 .

${ }^{21}$ (1905) 2Ir Pa. 319, 324. 
"If the owner of the whole fee conveys the coal in the land in general terms, as in this case, retaining the residue of the tract, the purchaser acquires the coal with the right to mine and remove it, provided he does so without injury to the superincumbent estate. His estate in the coal, like that of the owner of the surface, is governed by the maxim "sic utere tuo ut alienum non laedas." The owner of the surface is entitled to absolnte support of his land, not as an easement or right depending on a supposed grant, but as a proprietary right at common law: Carlin v. Chappel, 10I Pa. 348; i Snyder on Mines, sec. Iozo."

But it is equally well settled in Pennsylvania, as in England, that the "right and privilege" of letting down the surface can, by apt words, be created in the owner of the subjacent estate either through grant or through reservation. In the leading Pennsylvania case deciding this point, Scranton $v$. Phillips, ${ }^{22}$ the court said, by Mr. Justice Mercur:

"We see no reason why a person shall not be bound by his agreement to exempt another from liability for damages in working a coal mine, as well as from liability for damages resulting in the performance of any other kind of labor. No rule or policy of law forbids it. The undoubted intention of the parties to the contract was, that Fellows might mine and remove the coal without any obligation to support the surface or liability in case it fell. It was well said by Justice Blackburn, in Smith $v$. Darby et al., Law Rep., 7 Q. B. 7I6, 'the man who grants the minerals and reserves the surface is entitled to make any bargain he likes; both parties are just as much at liberty to make a bargain with reference to coals and minerals, as to make a bargain with reference to anything else.' The same rule applies when one grants the surface and retains the minerals. In each case the question is, did the parties agree there should be no obligation in regard to support?"

In a much later case, Miles v. Pennsylvania Coal Co., ${ }^{23}$ the same proposition was enunciated even more clearly and definitely by Mr. Justice Mestrezat:

"While, however, the owner of the surface is entitled as of natural right to its support by the owner of the subjacent mineral estate, it is equally well settled that the common owner of both estates, or the owner of the fee simple title to the tract of land, may by contract relieve the owner of the mineral estate from any duty to support the

\footnotetext{
23 (1880) 94 Pa. I5, 22.

23 (1907) 2I7 Pa. 449, 45I.
} 
surface and from liability for any injury or damage done to it by mining and removing all the mineral. Being the common owner of the whole title and, therefore, having the jus disponendi, he may make any legal disposition of the property he may desire. He may sell the coal and retain the surface, or he may sell the surface and retain the coal. In selling or leasing the coal, he may grant such rights to the vendee or lessee as either may desire or deem proper or necessary to remove the entire body of coal, as well as such rights in, through or over the surface as may be necessary for the same purpose. In other words, having the absolute dominion over the property he may grant such rights therein and thereto as may be agreed upon and are stipulated for in the contract. This naturally and logically follows from his ownership of the fee simple title to the property."

Let us next consider the change in legal relations resulting either from an alienation of the superjacent ("servient") estate or from an alienation of the subjacent ("dominant") estate.

First, suppose the superjacent estate is transferred. Does the transferee take subject to the "right and privilege" of the subjacent owner? That is, does the transferee get an aggregate of legal relations (rights, privileges, powers, and immunities) equivalent only to those that his grantor had-and no greater? Or, putting the same question in different form, does the transferee take subject to the same no-rights, duties, liabilities, and disabilities as his grantor was under? This question was, in substance, presented in Kellert $v$. Rochester \& Pittsburgh Coal $\&$ Iron $\mathrm{Co}^{24}$ In that case the original grant of the subjacent estate ran to the grantee "his heirs and assigns." But the language creating the privilege of letting down the surface did not expressly purport to "bind" subsequent takers from the grantor:

"And the said parties of the first part, do hereby release all and every claim or claims for damages to the said land caused by operating or working of said mines in a proper manner." 25

${ }^{24}$ (1909) $226 \mathrm{~Pa} .27,29$.

${ }^{25}$ It seems nothing short of remarkable that in instruments involving such important interests the draftsman should employ such loose and inexact language as appears in so many of the deeds on which the Pennsylvania decisions are founded.

The words, "release all and every claim or claims for damages to the 
Yet the court held, in effect, that the subsequent transferee took the superjacent estate subject to similar limitations as regards rights, privileges, powers, and immunities :

"On the trial of the cause as well as on the argument of the present motion to lift the nonsuit, it was contended that the release of damages contained in this deed bound the grantors alone, and did not extend to their grantees, the plaintiffs, since it is not in express words made to apply to the grantors, 'their heirs and assigns.' In my opinion this contention can find no support either in the law or the facts in this case. The deed from Samuel Craft and wife to Adrian Iselin in apt words conveys a fee in the coal, and the subsequent related stipulations and the release of damages to the surface that might result from the removal of the coal are germane to and an integral part of the grant. It was not necessary to repeat the words 'heirs and assigns' in connection therewith to make said stipulations and release apply to subsequent grantees of the surface land."

Second, let us assume that the subjacent estate, being already in existence along with the "right and privilege" of letting down the surface, is transferred to another. As conceded by the majority judges in Penman v. Jones, such "right and privilege" may by apt words be granted along with the existing subjacent estate. ${ }^{26}$ The previous Pennsylvania decisions supporting this proposition all seem, however, to be cases in which the conveyance to the subsequent grantee purported in express and specific terms

said land," purport, so far as direct meaning is concerned, to be a present release (extinguishment) of a secondary right (or "claim") to damages arising from breach of a primary right. Yet such secondary rights (or "claims") could not arise until the future. Obviously, what is really intended, so far as the grantor's rights, privileges, etc., are concerned, is an extinguishment of primary rights, privileges, etc. In correlative terms, the purpose is to create in the grantee of the subjacent estate immediate primary privileges, rights (or claims), powers, and immunities. It is of course entirely possible to express this purpose in unmistakably clear and precise terms. No doubt instruments more intelligently and artistically drawn in cases of this character would prevent serious controversy and save enormous waste from litigation.

Compare post, p. 79, n. 30.

${ }^{20}$ Madden v. Lehigh Valley Coal Co. (I905) 212 Pa. 63, 64 (subsequent grantee of the subjacent estate held to have privilege of letting down the surface; terms of his grant do not appear in the report); Stilley $v$. 
to grant the "right and privilege" along with the subjacent estate proper. Under such circumstances it was held both in Stilley v. Buffalo Co., ${ }^{27}$ and in Kirwin v. Del., L. \& W.R. R. $C_{0 .}{ }^{28}$ that the "right and privilege" passed, so that the subsequent grantee was privileged to let down the surface. It is significant, however, that no emphasis was in either case placed on the fact that specific terms had been employed for the purpose of alienating the "right and privilege." first case just mentioned Mr. Justice Elkin, speaking for the court, rested the result, very justly, on a broad foundation, viz., the intentions of the original grantor and grantee of the subjacent estate:

"Our cases relating to this question may very properly be divided into three classes: 1 . Those relating to grants of coal without any mention of damages to the surface by mining and removing the same; 2 . Those relating to grants of coal coupled with mining rights and the waiver of damages resulting by reason of the proper exercise of the mining privileges; and, 3. Those cases in which the grant of the coal together with mining rights is followed either by an express waiver of damages to the surface resulting from the removal of the coal, or by words importing such a waiver. . . . In the cases last cited it was expressly held that the rule giving to the owner of the soil the right of surface support had no application in a case in which the parties had otherwise covenanted. Like any other right, the owner of the surface may waive the right of surface support by his deed or covenant. It is therefore just as well settled that a surface owner may part with his right of surface support by a covenant to do so, as it is that the servitude of support is imposed upon the subjacent estate. The important question in cases of this character is whether the surface owner by express words or by necessary implication has waived the right of

Buffalo Co. (Igra) $234 \mathrm{~Pa} .492,497$ (deed to subsequent grantee of subjacent estate contained express and specific terms granting the right and privilege of letting down the surface); Kirwin v. Del., L. \& W. R. R. Co. (rgr5) $249 \mathrm{~Pa} .98$, roo (same as in preceding case).

${ }_{27}$ (I912) $234 \mathrm{~Pa} .492,497$.

28 (I9I5) $249 \mathrm{~Pa} .98$, ror.

- It is to be remembered that, as regards the Pennsylvania cases, the "right and privilege" have generally, if not always, been granted or reserved to the holder of the subjacent estates, "his heirs and assigns"; or else equivalent language has been used.

In Penman $v$. Jones, the original owner of the subjacent estate having been a corporation, the reservation was to the grantor, "its successors and assigns." 
surface support. The intention of the parties must and should govern. . . . The mining privileges granted were incident to the mining and removing of all the coal underlying the tract of land, and the covenant as to damages was in these words, 'hereby waiving all damages arising therefrom. If this waiver referred to damages to the land arising from the removal of all the coal, the case at bar is squarely ruled by Kellert $v$. Coal \& Iron Company, $226 \mathrm{~Pa} .27$. . . .

"In that case as in this the waiver of damages related to the land not included in the grant of the coal. . . . The grantor conveyed all the coal and no doubt intended to release all damages occasioned by the removal of it. As we have hereinbefore pointed out the release of damages in the present case related to the injuries resulting to the land by the removal of the coal, just as the waiver in the Kellert case above cited had reference to the land there in question." 30

In Graff Furnace Co. v. Scranton Coal Co. ${ }^{81}$ there is an important dictum tending to show that the "right and privilege" in question would ordinarily pass with the subjacent estate to a subsequent grantee. Said Mr. Justice Mestrezat, in delivering the opinion of the court:

"Equally true, however, is it that the owner in fee of the entire estate may grant the mineral estate and by apt words in the deed of conveyance may part with or release his right to surface support, and where he does so his grantee or those claiming through him may mine all the coal even though it should result in the surface falling in. The owner of the entire estate may likewise grant the surface of the land and reserve the mineral estate with

"As to the adequacy of language of "covenant," "agreement," "waiver," "release," etc., to create easements, compare Mr. Justice Holmes, in Hogan v. Barry (I886) 143 Mass. 538:

"There is no doubt that an easement may be created by words sounding in covenant. Bronson v. Coffin, 108 Mass. 175, 180 . If the seeming covenant is for a present enjoyment of a nature recognized by the law as capable of being conveyed and made an easement,-capable, that is to say, of being treated as a jus in rem, and as not merely the subject of a personal undertaking,-and if the deed discloses that the covenant is for the benefit of adjoining land conveyed at the same time, the covenant must be construed as a grant, and, as is said in Plowden, 308, "the phrase of speech amounts to the effect to vest a present property in you:" An easement will be created and attached to the land conveyed, and will pass with it to assigns, whether mentioned in the grant or not."

See also cases cited in Io Am. \& Eng. Ency. of Law (2d ed., I899) 4I4, n. I.

"(1914) $244 \mathrm{~Pa} .592,596$. 
the right to mine and remove it without liability for any injury or damage done to the surface, and in such case the grantor or those claiming through him may mine and remove all the coal without being compelled to support the surface."

The language of the last three quotations all imports that the "rights, privileges," etc., as to letting down the surface constitute an integral part of the subjacent owner's interest, just like the rights and privileges of "a right of way" appurtenant to the subjacent estate. ${ }^{32}$ Penman $v$. Jones, however, is evidently the first case to require or involve a more careful consideration of the exact nature of the subjacent owner's "right and privilege" and a classification of that form of legal interest either as an "easement" or as something other than an easement. As already intimated in dealing with a similar "right and privilege" concerning withdrawal of lateral support, ${ }^{33}$ it would seem that in Penman v. Jones the "right and privilege" reserved to A, its "successors and assigns" should have been treated as an easement, especially as regards the matter of alienation.

As Mr. Justice Moschzisker says in his dissenting opinion: ${ }^{34}$

"How shall the character of that right be defined? If it must be classed as an 'easement appurtenant,' then it would pass by a subsequent conveyance of the mineral estate. (Cathcart v. Bowman, $5 \mathrm{~Pa}$. 317; Horn v. Miller, I36 Pa. 640, 654, 20 Atl. 706, 9 L. R. A. 810; Richmond v. Bennett, 205 Pa. $470,472,55$ Atl. I7; Held v. McBride, 3 Pa. Super. Ct. I55, I58; Citizens' Elec. Co. v. Davis, $44 \mathrm{~Pa}$. Super. Ct. I38, I42; Dority v. Dunning, $78 \mathrm{Me}$. 381, 384, 6 Atl. 6; Winston v. Johnson, 42 Minn. 396, $402,45 \mathrm{~N}$. W. 958 ), unless some exceptional rule applies to an easement of this particular kind. An easement 'is generally defined to be a "liberty, privilege or advantage which one may have in the lands of another without

"Compare Mr. Justice Mestrezat in Miles v. Penn. Coal Co. (rgo7) 2 I7 $\mathrm{Pa}$. 449, 45I.

In this case the learned judge's language is such as to lump together, as of the same nature, both a right of way and a "right and privilege" of letting down the surface:

"In selling or leasing the coal, he may grant such rights to the vendee or lessee as either may desire or deem proper or necessary to remove the entire body of coal, as well as such rights in, through or over the surface as may be necessary for the same purpose."

${ }^{8}$ See ante, pp. 73-74.

24 Penman v. Jones (1917) 100 Atl. 1043, 1047-1048. 
profit." Big Mountain Improvement Co.'s App., $54 \mathrm{~Pa}$. 36I, 369. Jones on Easements, at page 4, states their qualification thus:

'First, they are incorporeal; second, they are imposed on corporeal property; third, they confer no right to a participation in the profits arising from such property; fourth, they are imposed for the benefit of corporeal property; fifth, there must be two distinct tenementsthe dominant, to which the right belongs, and the servient upon which the obligation rests. . . .'

"Thus it may be seen that the right created in the grantor by the deed from A. to B. has all the attributes of an easement appurtenant to the mineral estate vested in the former. It is an incorporeal right attached to corporeal property, and, when brought into legal existence, generally speaking, it would pass upon a conveyance of the latter under the general description of 'appurtenances.' Id., sec. 20 et seq., and cases hereinbefore cited."

Various authorities support the conclusion here suggested as sound. ${ }^{95}$

sowbothan v. Wilson (r857) 8 E. \& B. I23, affd. 8 H. L. Cas. 348. Compare Aspden v. Seddon (1875) Io Ch. App. 394, 402; Wilms v. Jess (I880) 94 Ill. 464, 468 (reasoning and dicta).

In Aspden v. Seddon, supra, Mellish, L. J., said:

"Now, by the deed, all mines and seams of coal, ironstone, and other minerals are reserved to Stott, with full liberty, power, and authority for Stott and his lessees 'to search for, get, win, take, cart and carry away the same, and sell or convert to his or their own use the said excepted mines, veins and seams of coal, cannel, and ironstone and other mines and minerals, or any of them, or any part or parts thereof, at pleasure, and to do all things necessary for effectuating all or any of the aforesaid purposes.' ... If the sentence had stopped there, these words would be consistent with the construction that the mineral owner may take away every part of the minerals, provided he can do so without violating the surface-owner's right to support, but not otherwise, and some further words would be necessary to prove that the intention of the parties was that the mineral owner should be at liberty to take away the whole or any part of the minerals, notwithstanding he might thereby let down the surface or any buildings thereon. Accordingly the Respondents rely on the words which immediately follow in the deed as sufficient for this purpose. Those words are, 'but without entering upon the surface of the said premises, or any part thereof, so that compensation in money be made by him or them for all damage that should be done to the erections on the said plot by the exercise of any of the said excepted liberties or in consequence thereof.'

"As by the express words of the reservation the mine-owner in working the mines is not to enter upon the plot of land conveyed by the deed. the damage to the buildings for which compensation is to be given must be damage to the buildings caused by the removal of the minerals reserved, and therefore it follows that $a$ right to remove all the minerals, notwithstanding the buildings above might be thereby damaged, was one of the liberties reserved by the deed. . . .

"It was argued on the part of the Appellants, that the right to com- 
The contrary opinion of the majority judges in Penman $v$. Jones seems to be founded on four interesting and crucial points which may be indicated and discussed as follows: (a) The court's reliance on cases involving an original "severance" of the superjacent and subjacent estates; (b) The court's confusing of the subjacent owner's legal privilege of removing surface support, etc., with the superjacent owner's right (in the sense of "legal claim") that another person shall not remove the surface support; (c) The court's reasons for refusing to treat the interest as an easement; (d) The court's explanation of the interest as an "irrevocable license." Each of these matters must here be treated with as great brevity as may be consistent with clearness :

(a) The court's reliance on cases involving an original "severance" of the superjacent and subjacent estates. The court begins its argument by quoting from a series of cases running from Jones v. Wagner ${ }^{36}$ to Youghiogheny River Coal Company v. Allegheny National Bank, ${ }^{37}$ the court's quotation from the latter case having already been reproduced at an earlier point in the present discussion. $^{38}$ All of such cases announce merely the well settled doctrine that the holder of the superjacent estate, at the moment of "severance," has, apart from grant or reservation, etc., a so-called "natural" right of surface support; or, correlatively, that the owner of the subjacent estate has immediately the duty of not causing collapse through removal of support: that is, has no privilege of causing collapse, etc. These cases, which are in entire accord with the authorities at large, would seem very diffcult of application to the situation in Penman v. Jones. In that

pensation was merely an additional remedy given to the surface-owner in case his buildings were damaged, but did not give the mine-owner a right to get the minerals in such a way as to cause damage to the buildings. It seems to us, however, clear that the compensation is given for damage caused by rightful acts which the deed makes lawful, and not for damage caused by wrongful acts. The exercise of any of the excepted liberties must surely apply to rightful acts, and not to wrongful acts, because it is absurd to suppose that a liberty is reserved to do wrongful acts. If liberty is reserved to do the act complained of, that reservation, as between the parties and those claiming under them, makes the act rightful."

In Rowbotham v. Wilson, supra, the judges, both of the Exchequer Chamber and of the House of Lords deliberately and definitely characterized the interest in question as an easement. The important passages to this effect are quoted post, pp. 90-9I.

* Jones v. Wagner (1870) $66 \mathrm{~Pa} .429,434$.

or (I905) 2II Pa. 319, 324.

For the court's quotation from this case, see ante, pp. 74-75. 
case the subjacent estate had already been "severed" for eighteen years; and the "right and privilege" of letting down the surface, having at the moment of "severance" been created as an integral part of the subjacent owner's aggregate of legal relations, had had a similar period of life. The transfer of the subjacent estate and its accompanying "right and privilege" was, at that moment, a matter admittedly concerning only the subjacent owner and his transferee: the superjacent owner had no power to prevent the alienation of the "right and privilege." Whatever we call the "right and privilege," its transfer along with the subjacent estate proper would be like the transfer of an existing easement, not like the creation of a new easement at the moment of severance.

Yet the majority opinion, immediately after the quotation from Youghiogheny River Coal Co. v. Allegheny National Bank, ${ }^{37}$ continues as follows:

"In the light of the foregoing authorities, it is clear that there is nothing in the language of the deed from the Lackawanna Iron \& Coal Company to the steel company, which can be regarded as indicating an intention to convey the minerals free from liability upon the part of the purchaser to support the surface in their removal. No such privilege follows from the mere conveyance of coal, machinery, fixtures, tools, etc., with the 'hereditaments and appurtenances' belonging thereto. The conveyance of 'all the estate, right, title, interest, benefit, property, claim and demand whatsoever' of the grantor, is properly referable to the subject-matter of the grant, to wit, the coal conveyed, and does not necessarily amount to a waiver of the right of the grantor to insist upon support being left for the surface."

(b) The court's confusing of the subjacent owner's legal privilege of removing surface support, etc., with the superjacent owner's right (in the sense of legal claim) that another person shall not remove surface support, etc. Let us consider certain passages from the court's opinion in juxtaposition:

(I) "No such privilege" [of removing surface support ("free from liability")] "follows from the mere conveyance," etc. (From above quotation.)

(2) "The conveyance ... is properly referable to ... the coal conveyed and does not necessarily amount to a waiver of the right of the grantor to insist upon support being left for the surface." (From above quotation.) 
(3) "The insertion" etc. . . "indicates an intention upon the part of the grantor not to waive the right of support as to other lots" [including superjacent lot in question]. (Later passage.)

(4) "In the present case, whatever right" [privilege] "the coal company retained to interfere with the surface support was relinquished by it to the Scranton Trust Company" [D], etc. (Still later passage.)

This is not simply a matter of terms, as such: it is a matter of basic legal conceptions constituting the very essence of the court's reasoning. ${ }^{39}$ In the first and fourth passages, the court is dealing with "privilege-no-right" relations; in the second and third passages with "right-duty" relations. More specifically, in the first and fourth passages the question is whether the "privilege" of A, the Coal Company, (the correlative "noright" being in $\mathrm{B}$, the superjacent owner) has been alienated to another person-in passage "(I)" to C, the Steel Company, in passage "(4)" to D, the Trust Company. But in the second and third passages that question is treated as identical with the question whether "the grantor" of the subjacent estate has made a "waiver" of "the right" [= claim] "of support" as to B's lot. ${ }^{40}$

As, of course, the ownership of the superjacent lot in question was in $\mathrm{B}$ at the time the conveyance of the subjacent estate was made, it is clear that the grantor of the subjacent lot had no "right of surface support" to waive or extinguish. It is clear that he had no such right, or claim, against himself; and it is equally clear that he had no such "naked" rights, or claims, against C (the Steel Company) or anyone else. Such grantor

Similar serious difficulties as regards the application of fundamental legal conceptions are to be found in Graff Furnace Co. v. Scranton Coal Company (1914) $244 \mathrm{~Pa} .592,598$.

«D Elsewhere in the opinion, Penman v. Jones (1917) roo Atl., at 1046, more baffling language is used:

"The Scranton Coal Company has no direct interest in this case; but, considering that its rights might be affected by the conclusion herein reached, it presented a brief, and has been represented by counsel, who among other points raised, have contended that, if the deed from the coal company to the steel company did not pass to it the waiver of liability for failure to support the surface which had been retained by the coal company, then the deed to the trust company was also insufficient to release or reconvey that waiver to the owner of the surface. But this contention overlooks the fact that the law gives to the owner of the surface the right to subjacent support of his land in its natural condition, as a result of, and as an incident to that ownership." 
had (apart from various powers and immunities not now necessary to be considered) merely the "right and privilege" of removing the surface support (and causing damage thereby), i. e., the privilege of removing support, and the rights, or claims, that all others, including $B$, the superjacent owner, should not interfere with his privileged acts of removing such support, etc. These rights, or claims, against interference are, of course, entirely different from any supposed right, or claim, that such surface support should not be removed. Similarly, in the "right of way" case heretofore put, with X owning the dominant tenement, Blackacre, and $\mathrm{Y}$ owning the servient tenement, Whiteacre, it is clear that X's privileges of crossing Whiteacre and his rights of non-interference against $Y$ and others are entirely distinct from Y's rights, or claims, that others than $\mathrm{X}$ shall not trespass on Whiteacre.

Very possibly, had the learned Pennsylvania court seen that, as regards the conveyance of the subjacent estate to $C$ (the Steel Company) it was not dealing with "the grantor's" natural "right of surface support," the decision of the case would have gone the other way. ${ }^{41}$ A similar suggestion may, indeed, be ventured as regards the earlier case of Graff Furnace Co. $v$. Scranton Coal Co., ${ }^{42}$ involving a somewhat different question of great importance to mining interests. In any event, it seems altogether likely that in Penman v. Jones, had there been a more careful discrimination and application of fundamental legal conceptions as above specified, the court would have realized the inapplicability of the series of cases running from Jones $v$. Wagner ${ }^{43}$ to Youghiogheny River Coal Co. v. Allegheny National Bank. ${ }^{43}$

(c) The court's reasons for refusing to treat the "right and privilege," as an easement. For the proposition that the "right and privilege" of letting down the surface was not an easement, the majority judges cite no authorities; and their own argument

4 Compare Mr. Justice Holmes, in The Path of the Law (1897) Io HaRv. L. REv. 456, 474-475:

"Therefore, it is well to have an accurate notion of what you mean by law, by a right, by a duty, by malice, intent, and negligence, by ownership, by possession, and so forth. I have in mind cases in which the highest courts seem to me to have floundered because they had no clear ideas on some of these themes."

2 (19I4) 244 Pa. 592, 598.

¿See ante, p. 74, n. 20. 
is as follows, the various portions thereof being consecutively numbered and paragraphed by the present writer so as to facilitate subsequent reference:

"(I) This stipulation cannot properly be regarded as the creation of another easement appurtenant to the mineral estate, which would pass merely with its conveyance. The stipulation for the right to remove the coal without liability for injury to the surface did not have the effect of retaining in the grantor any interest outside of the coal, in the land which was being conveyed. It did not authorize the grantor to do anything upon the land of the surface ozener, but its effect was merely to absolve the owner of the coal from responsibility for injurious consequences which might follow the removal of the coal. The stipulation may fairly be considered as being a license to do the desired act, that is, to let down the surface, if necessary, in order to remove the coal. It was authority to do an act affecting the land, without, however, conferring upon the licensee any estate in the land. An easement is always an estate in the land.

"(2) But 'a license properly passeth no interest, nor alters or transfers property in anything, but only makes an action lawful, which without it had been unlawful.' Thomas v. Sorrell, Vaughan's Rep. (Eng.) 330, 35I. It is distinguished in this from an easement. Jones on Easements, 64, 65. The only effect of the stipulation in this case would be to make lawful the letting down of the surface, which otherwise would be unlawful. Further than that, it could not go. coal.

"(3) Its force would be spent with the removal of the

"(4) The license in this case, being coupled with a grant of the coal, or rather with the reservation of the coal, was irrevocable by the owner of the surface, and was assignable by the licensee.

"(5) Beyond question the coal company had pozer to assign to the steel company its right to remove the coal without liability for injury to the surface, but it did not see fit to do so."

In this argument the first point to emerge is that "the right and privilege" did "not authorize the grantor to do anything upon the land of the surface owner," and that it was only "authority to do an act affecting the land." The mere assembling of the two parts of this proposition would seem sufficient to show how attenuated is the objection urged. The privilege of causing the surface owner's land to collapse would seem a more substantial affirmative privilege than the privilege of walking "upon" the 
surface of the subjacent owner's land. For the living law affecting practical coal miners the distinction laid hold of appears, at best, purely arbitrary: it has no teleological basis in relation to the general purposes intended to be achieved by the law of easements. Still looking at the privilege elements alone, we may profitably compare the well-recognized easement of making disagreeable noises on one's own land so as to cause annoyance to the owner of adjacent land. ${ }^{44}$ It is interesting, in the same

" See Sturges v. Bridgman (I879) II Ch. D. 852, 857, 858, 864. In this case the claim of easement by prescription was rejected by the court; but it is recognized in the opinions of Jessel, M. R., and Thesiger, L. J., that such an easement could be created by grant. Jessel, M. R., said, at pp. 857-858:

"There are really all sorts of difficulties in the defendant's way. In the first place the easement must be an easement "upon, over, or from." Now the noise in question, in my opinion, is not properly described in that way. No doubt the waves by which the sound is distributed pass over the plaintiff's land; there is no question about that. But is that an easement enjoyed 'upon, over, or from any land?' Well, I think it is not. That appears not only from the natural meaning of the words, but from authority. .. He claims the right of setting the air or ether in motion by something or other that he does upon his own property."

Thesiger, L. J., said, at p. 864 :

"The passage of water from his land on to yours may be physically interrupted, or may be treated as a trespass and made the ground of action for damages, or for an injunction, or both. Noise is similar to currents of air and the flow of subterranean and uncertain streams in its practical incapability of physical interruption, but it differs from them in its capability of grounding an action."

Compare also, as regards noises and odors, Elliotson v. Feetham (I835) 2 Bing. N. C. I34, I37; Bliss v. Hall (1838) 4 Bing. N. C. 183, 186; Ball v. Ray (1873) L. R. 8 Ch. App. 467, 471.

Such an easement is generally classified as an affirmative or positive one. See, e. g., Leake, Uses and Profits of Land (1888) 193:

"The transmission and diffusion of noise or noxious vapours over the servient tenement is a positive easement which cannot be effectually opposed by physical obstruction; the only mode of resisting it is by action, when it amounts to an actionable nuisance."

Compare also Salmond, Torts (4th ed., I9I6) 260-26r :

"A positive easement is a right to enter upon the servient land or to do some other act in relation thereto which would otherwise be illegal. A negative easement is a right that the owner of the servient land shall refrain from doing some act which he would otherwise be entitled to do$e$. , the erection of a building which would obstruct his neighbour's lights. In other words, the obligation of the owner of the servient land consists either in patiendo (i. e., in suffering the dominant owner to do an act on or in relation to the servient land) or in non faciendo (i. e., in refraining from doing some act on the servient land). In the first case the servitude is positive, and in the second negative. . .

"The chief recognized easements are . . (6) rights to do some act which would otherzerise amount to a nuisance to the servient land." 
connection, to notice the easement (as distinguished from "natural" right) of lateral or subjacent support for a building leaning against or resting upon a structure belonging to the servient land. ${ }^{45}$ Turning from privileges to rights (claims),

${ }^{4}$ Compare Lord Chancellor Selborne, in Dalton v. Angus (I88r) L. R. 6 App. Cas. 740, 793-795:

"I think it clear that any such right of support to a building, or part of a building, is an easement; and I agree with Lindley, J., and Bowen, J., that it is both scientifically and practically inaccurate to describe it as one of a merely negative kind. What is support? The force of gravity causes the superincumbent land, or building, to press downward upon what is below it, whether artificial or natural; and it has also a tendency to thrust outwards, laterally, any loose or yielding substance, such as earth or clay, until it meets with adequate resistance. Using the language of the law of easements, I say that, in the case alike of vertical and of lateral support, both to land and to buildings, the dominant tenement imposes upon the servient a positive and a constant burden, the sustenance of which, by the servient tenement, is necessary for the safety and stability of the dominant. It is true that the benefit to the dominant tenement arises, not from its own pressure upon the servient tenement, but from the power of the servient tenement to resist that pressure, and from its actual sustenance of the burden so imposed. But the burden and its sustenance are reciprocal, and inseparable from each other, and it can make no difference whether the dominant tenement is said to impose, or the servient to sustain, the weight.

"Lord Campbell in Humphries v. Brogden referred to the servitude oneris ferendi (applied in the law of Scotland to a house divided into 'flats' belonging to different owners), as apt to illustrate the general law of vertical support. The servitude so denominated (ut vicinus onera vicini sustineat) in the Roman law was exclusively 'urban,' that is, relative to buildings, whether in town or country; and the instances of it given in the Digest refer to rights of support acquired by one proprietor for his building, or part of it, upon walls belonging to an adjoining proprietor: Inst. lib. 2, tit. 3 ; Dig. lib. 8, tit. 2, sects. $24,25,33$; also tit. 5 , sects. 6,8 . But, in principle, the nature of such a servitude must be the same, whether it is claimed against a building on which another structure may wholly or partly rest, or against land from which lateral or vertical support is necessary for the safety and stability of that structure.

"The pressure of the dominant tenement, in the case of support, is upon the soil of another man's land, and I can see no material difference between this and 'something positive done or used in the soil of another man's
land.'"

Compare to similar effect, Lord Watson, at p. $83 \mathrm{I}$.

The above quotation seems, for present purposes, not without significance and interest even if one must think that there is in Lord Selborne's opinion an unfortunate failure to discriminate between "right" and "privilege" elements in the various easements that he discusses. The privilege of pressure against the neighboring soil would doubtless exist as a "natural" or ordinary privilege quite independently of any easement proper.

See, to this effect, Mr. Justice Lindley and Mr. Justice Bowen, S. C., L. R. 6 App. Cas. 740, 764, 784. As Lord Bowen says, at p. 784:

"There is certainly no case which decides that this pressure gives rise to a right of action on the neighbour's part, and practical reasons of 
the court apparently overlooks, and certainly ignores, the fact that the subjacent owner was, at the time of severance, granted, in express terms, rights (claims) as well as privileges-the "right and privilege," etc. That is, as in the case of a right of way, the subjacent owner would have rights, or claims, that the superjacent owner and third parties should refrain from disturbance of the exercise of his privileges of doing that which might cause the collapse of the superjacent owner's land. If it were not for these "right (claim)" elements in the subjacent owner's interest, very possibly the superjacent owner might, through operations conducted partly on his own land, prevent the subjacent owner's removal of surface support. These rights, or claims, of the subjacent owner correspond, pro tanto, to the negative rights constituting the chief elements in the ordinary easement of light.

A second point urged in the Pennsylvania court's argument is that "its force" [that is the force of the stipulation for the "right and privilege" of letting down the surface] "would be spent with the removal of the coal." The suggestion seems to be that the indefinite duration of the "right and privilege" tends to show that no "estate" and hence no "easement" was created in favor of the subjacent owner. But it is clear that even an easement may exist as a freehold interest of uncertain duration; ${ }^{46}$

convenience may be adduced against such a surmise, although it might perhaps be argued that an action ought on principle to lie against, and an injunction be obtainable to restrain, the man who is actually availing himself of his neighbour's soil and using it in a manner which in twenty years will be evidence of the acquisition of a right so to do."

"See Hewlins v. Shippam (1826) 5 B. \& C. 221, 228, per Bayley, B.:

"The declaration claimed the right as a license and authority granted to the plaintiff's landlords, their heirs and assigns, to make the drain, and have the foul water pass from their scullery through the drain across the defendant's yard. One of the counts claimed it indefinitely, without fixing any limits; others restricted it either to the time the defendant should continue possessed of his yard or house, or so long as it should be requisite for the convenient occupation of the plaintiff's house; some stated, as part of the consideration that defendant's landlord should do some repairs to the defendant's premises; others did not. Now, what is the interest these counts stated? "A freehold interest."

An easement may even exist merely as an interest "for years." As said by Strong, J., in Huff v. McCauley (I866) $53 \mathrm{~Pa}$. St. 206, 210:

"All easements and profits a prendre may be held for life, in fee, or for years."

See, in accord, Alderson, B., in Wood v. Leadbitter (1845) I3 M. \& W. 838,843 . 
so that it is difficult to see the force of the suggested objection. As the "right and privilege" was reserved to the owner of the subjacent estate, "its successors and assigns," there was clearly an attempt to create an interest in fee; and the uncertainty of possible duration would seem immaterial.

Neither of the two points directly urged in Penman $v$. Jones to show that the "right and privilege" in question could not be an easement is supported in any case cited by the Pennsylvania court; and such authorities as have been observed by the present writer are opposed in reasoning or in decision.

The leading English case is Rozebotham v. Wilson; ${ }^{47}$ and the following passages are instructive:

Bramzell, B.: "The first question is, Can there be a right to take the mines and remove all support from the surface? . . . I cannot see how, if there may be a grant of mines, and of the right to enter, sink shafts, and work, there may not be such a grant as that contended for here. Nor can I see how, if a grant of the right of unobstructed light and air, or of support of the soil, to an adjoining owner, would be good, a grant of such a right as claimed here would not be. . . But another objection is taken. It is said that all easements suppose a right exercised over the servient tenement: even in the case of lights it is the passage of the rays of light and of air; and in the support of the neighbouring soil it is its continuance in its place; and that the claim of the defendant here is not to do something on the plaintiff's land, but merely not to be sued for what he does on his own. It is no answer to this objection to say that it is exceedingly subtle. It certainly would be strange if such a right could not be given with a grant of an estate in the mines, but could to a licensee; and yet to the latter the objection would not apply. And I think the true answer to it (assuming the defendant claims an easement) is, that the rules which are applicable to the owners adjoining vertically, which is the natural order, are not applicable where there is an unusual order of things, viz. a division of horizontal ownership. I think, therefore, such a right may exist. . . ."

Martin, B.: "In the present case, the Commissioners and Samuel Pears, in the same instrument by which the former executed their powers, the latter under his hand and seal, for a valuable consideration to himself, declared that the mines below the land allotted to him should belong to Henry Howlette in fee simple, and his own lands be subject to the incident or quality that the

${ }^{47}$ (I857) 8 E. \& B. I23; affirmed 8 H. L. Cas. 348. 
owner of the mines should not be responsible for any injury to the surface consequent upon the working of them. In my opinion, the incident was lawfully created, and attached to the estate of Samuel Pears; and that he and all persons claiming under him took the estate subject to it."

Williams, J.: "But it cannot, I think, be doubted that, if an owner of land with subjacent mines were to grant away the mines together with the power of winning the minerals, without regard to any injury done thereby to the surface, such a grant would be good, and would bind the inheritance, and his estate in the surface would pass to his assigns abridged, to that extent, of the right of support from the minerals, whatever the nature of that right may be. Hence it seems to follow that it is competent for the owner of the surface of land effectually to curtail by grant in favour of the owner of the subjacent mines, the right to support therefrom."

Lord Wensleydale: "And supposing this power is not to be considered as given by the act of the Commissioners, but only by the contract of the parties, Pears' covenant, he being seised in fee by virtue of the award, would certainly operate as a grant, by him, to Howlette (who, at the same instant, took the fee simple in the mines), of the power to get the minerals, and to disturb the surface of his own land for that purpose by winning the mines below from some adjoining land or bed of coal.

"I do not feel any doubt that this was the proper subject of a grant, as it affected the land of the grantor; it was a grant of the right to disturb the soil from below, and to alter the position of the surface, and is analogous to the grant of a right to damage the surface by a way over it; and it was admitted, at your Lordships' bar, that there is no authority to the contrary."

In Ryckman v. Gillis, ${ }^{48}$ a New York case concerning lateral support, Johnson, C., who dissented only on points not now involved, expressed views in accord with the English cases:

"But if the right to have support from adjoining land be not an easement, then what may be called the antagonistic right of removing your own soil so as to diminish the support to which the adjoining owner was entitled, is an easement affecting his land in favor of yours, and making his land the servient tenement in that regard, and subject to the easement of being deprived of its natural support. That such an easement may be acquired by grant or agreement of the parties is obvious, and has been

(I874) 57 N. Y. 68, 78. 
settled by repeated adjudications between surface owners and mine owners underneath. Rowbotham v. Wilson and Smart v. Morton are instances establishing further that the party claiming the ordinary rule not to be applicable must establish its renunciation by the other party."

(d) The court's explanation of the "right and privilege" of letting down the surface as an "irrevocable license." The limitations of space forbid here any attempt to discuss comprehensively and thoroughly the numerous and troublesome classes of cases commonly associated with the chameleon-hued term, "license." Like the terms "res gestae" and "estoppel," "license" may be said to be a word of convenient and seductive obscurity; and the task of dealing at all adequately with the intricate and confused subject would, in and of itself, require a long article. ${ }^{49}$ In this place, therefore, only a few suggestions may be ventured-with particular reference, of course, to paragraphs " 2 " and " 4 " of the above-quoted argument from Penman v. Jones.

In spite of such ambiguities as attach to the term "license," it would seem that the court's effort to fit that legal category to the "right and privilege" of letting down the superjacent land encounters not only the supposed objections to its being considered an easement, ${ }^{50}$ but also several additional ones.

19 Many of the difficulties would be removed if effort were made to confine the term "license" to that group of operative facts which constitute a "mere permission" to do or cause, or not to do or cause, a given thing. Instead of this, the term is rapidly shifted about by lawyers and courts,usually even by the more careful writers,- -so as to cover not only more complex groups of operative facts, but also the jural relations flowing either from a "mere permission" or from such more complex sets of facts. See, e. g., Salmond, Torts (4th ed., Igr6) sec. 76 (compare the usage in paragraphs " $I$ " and " 2 ").

For more general consideration of these difficulties, see (Igr3) 23 YALE LAw Journal, 16, 20, 44; and compare (1917) 26 YALE LAw JouRNal, 7 Io, 725, n. $34 ; 755$, n. 90.

${ }^{50}$ In directly negativing the contention that the "right and privilege" constituted an easement, the court said that the "stipulation" did "not authorize the grantor to do anything upon the land of the surface owner," and that it was only "authority to do an act affecting the land." If any distinction of this kind is to be pressed, has the category of license any greater chance?

A typical definition is to be found in Tiffany, Real Property (1903) 678:

"A license given to a person to do something on the land of another should be carefully distinguished from an easement. A license is a mere permission to do something on another's land."

A so-called "license" resulting, when "executed," in the extinguishment 
Quoting the well-known dictum of Vaughan, C. J., in Thomas v. Sorrell, ${ }^{\text {,1 }}$ the Pennsylvania court says, inter alia: "An easement is always an estate in the land. But 'a license properly passeth no interest, nor alters or transfers property in anything," " etc.,- the further point being that the "right and privilege" of letting down the surface is a "license," hence not an "interest," and hence also not an easement. It is clear, however, that in the passage quoted Chief Justice Vaughan was referring exclusively to a simple case not at all like that of Penman $v$. Jones. This is shown impressively by the examples which the learned chief justice himself gives immediately after the words quoted by the Pennsylvania court:

"A dispensation or licence properly passeth no interest, nor alters or transfers property in any thing, but only makes an action lawful which without it had been unlawful. As a licence to go beyond the seas, to hunt in a man's park, to come into his house, are only actions, which without licence, had been unlaw ful.

"But a licence to hunt in a man's park, and carry arvay the deer kill'd to his ozen use; to cut down a tree in a man's ground and to carry it away the next day after to his own use, are licences as to the acts of hunting and cutting down the tree; but as to the carrying awray of the deer kill'd, and tree cut down, they are grants.

- "So to licence a man to eat my meat, or to fire the wood in my chimney to warm him by, as to the actions of eating, firing my wood and warming him, they are licences; but it is consequent necessarily to those actions that my property be destroyed in the meat eaten, and in the wood burnt, so as in some cases by consequent and not directly, and as its effect, a dispensation or licence may destroy and alter the property."

of an existing easement is, of course, to be distinguished. Such a "license," for example, when given by the owner of an easement of light, extinguishes, before execution, pro tanto, and, after execution, in toto, the rights or claims of the easement owner, so far as the particular obstruction is concerned. But such extinguishment amounts simply to a new creation ("restoration") of the former "natural" privilege or privileges of the owner of the servient tenement. See Winter v. Brockwell (I807) 8 East, 308 (as explained by Bayley, B., in Hewlins v. Shippam (I826) 5 B. \& C. 221, 233); Morse v. Copeland (I854, Mass.) 2 Gray, 302.

It is obvious, moreover, that such "natural" privileges, on being thus "restored," would pass, even without express mention, to any subsequent grantee of the estate of which they are constituent elements.

si (1672) Vaughan, 330, 351. 
Suppose that $R$ says to $S$, "I give you permission to walk across my land, Longacre." This language, in and of itself, purports merely to create in $S$ the privilege, or, more strictly, series of privileges, of walking across R's land. ${ }^{52}$ In correlative terms, R's rights that $S$ stay off are extinguished, and no-rights substituted. The important point is that the permission constitutes a grant to $\mathrm{S}$ of privileges alone: $\mathrm{S}$ is not granted any accompanying rights (or claims) that $\mathrm{R}$ or other persons shall not interfere with S's entering on the land, Longacre, and walking across. If, therefore, $S$ succeeds in entering on the land, no rights (or claims) of $R$ are violated; but, if, on the other hand, $\mathrm{R}$ closes the gate in the high stone wall, or bars the one and only path midway, no rights (or claims) of $S$ are violated ${ }^{53}$ and so also if some third party locks the gate or bars the path half way across Longacre. ${ }^{54}$ Further than that, it is assumed,

${ }^{82}$ Of course the creation of such privilege or privileges amounts, in other words, to an extinguishment of S's duty or duties to stay off R's land.

${ }^{* 3}$ See, for a full explanation of this matter (Igr3) 23 YALE LAW JoURNAL, 16, 35 seq.

sh Compare Wood v. Leadbitier (1845) I3 M. \& W. 837; Hill v. Tupper (1863) 2 H. \& C. 121, also cases cited in comment entitled, Right of Ticketholder to Recover in Tort (I9I7) 26 YALE LAW Journal, 395. But cf. Case v. Webber (1850) 2 Ind. 108.

In Hill v. Tupper, supra, no doubt the deed of grant was intended to create a substantial interest-an "easement in gross"; and the explanation of the actual decision lies in the fact that, so far as pure "legal" doctrine was concerned, such an interest in gross could not be created in England. See Ackroyd v. Smith (1850) ro C. B. I64. Compare a very recent case, Sports \& General Press Agency v. "Our Dogs" Publishing Co. (Igr6) 2 K. B. 880 ; affd. (Igr7) 6r S. J. (C. A.) 299.

In Wood $v$. Leadbitter, supra, the intentions of the parties were evidently similar,- that is the unsealed ticket to the race course was intended to grant both "irrevocable" privileges and "irrevocable" rights; but that purpose failed both because, even if the intended interest were permissible though not "coupled with a grant," the common law would require a deed for the creation of such an "incorporeal" interest (even "for years"), and because such an interest was not deemed a permissible one when not coupled with a grant such as that involved in a profit or such as that exemplified by Wood v. Manley (I839) II A. \& E. 34 (see post, p. 97, n. $58 \mathrm{a}$, and p. I00). It would seem, also, that-the plaintiff's pleading was faulty, his replication of "leave and license" as of the time of the battery not being sustained by the facts.

For the later English authorities concerning an unsealed written permission given for consideration and expressed to be for a continuous period, definite or indefinite, see the important case of Hurst v. Pictures Co., Ltd. [19I5] I K. B. I, involving a theatre ticket and depending on the "con- 
in accordance with the actually existing law, that $R$, instead of exercising his physical power of closing the gate or barring the path, might exercise his legal power of extinguishing S's series of privileges: that is, $R$ might simply say to $S$, "I withdraw my permission."

What shall we say of this "uncompanioned" "privilege-noright" relation (or series of such relations) thus vested in S subject to the liability of being extinguished by R's exercise of his legal power of "revocation?" Was Chief Justice Vaughan strictly correct in asserting, in effect, that a mere privilege of this kind is not an "interest" or "property" in land? Very likely, as Thomas $v$. Sorrell was decided in 1672 , some years before the Statute of Frauds, he put it so on the assumption that, if it were recognized as an "interest" in land, a deed would be requisite to create such a privilege, just as in the usual case of "incorporeal" interests. ${ }^{55}$ Possibly also, as is so often the case even at the present day, he failed to see that a "privilege-no-right" relation is as true a legal relation and advantage as is a "rightduty" relation. ${ }^{56}$

But, whatever his reasons, it is submitted that his statement is, strictly and analytically considered, erroneous; and that it has had its full measure of influence in confusing the vast number of later judicial discussions and decisions relating to the subject. The "privilege-no-right" relation of $S$ or, a fortiori, a series of such relations seems indeed to be an "interest" in land, although it be unaccompanied by rights (or claims) and even though $S$ be under a liability of having his privilege or privileges divested as already indicated. If, for example, $M$ were a judgment debtor and his land, Redacre, were about to be sold by the sheriff, M's privileges concerning Redacre would be substantial elements in his total ozenership or interest, even in spite of the liability of their being divested by the exercise of the sheriff's power under the writ of execution.

If all this be so, it would seem that the more accurate and satisfactory way to meet the supposed objection as to a deed

flict" of substantive "legal" and "equitable" rules and the determining of their "net effect" under the Judicature Acts.

For explanation of the latter, see the writer's articles. The Relations between Equity and Law (I9I3) II MICH. L. Rev. 537; and The Conflict of Equity and Law (I9I7) 26 YALE LAW JouRNAL, 767, 770.

${ }^{\infty}$ See Hewlins v. Shippam (1826) 5 B. \& C. 221, 229; Wood v. Leadbitter (I845) I3 M. \& W. 838. See also preceding note.

${ }^{s}$ See ante, p. 7I, notes I2 and I3. 
is to recognize that the creation of a very limited interest such as $R$ gave to $S$ was never within the contemplation of the rule that an "incorporeal" interest. in land must be created by deed. Similarly, after the Statute of Frauds, the privilege or series of privileges over Longacre, even though frankly conceded to be an "interest," might well be held not within the intention of Section $I$, requiring a writing for the creation of interests in land. ${ }^{.7}$

But it is necessary to hurry along to the next step in the Pennsylvania court's reasoning. After quoting Chief Justice Vaughan's dictum ${ }^{58}$ concerning a mere temporary and revocable privilege in order to show that the "right and privilege" of letting down the surface was not an "interest" or "estate," the learned court proceeds to assert that "the license [in Penman v. Jones], being coupled with a grant of the coal, or rather with the reservation of the coal, was irrevocable by the owner of the surface, and was assignable by the licensee." That is, the assumption is made,-erroneously, it would seem,-that Chief Justice Vaughan's language applies not only to a temporary and revocable privilege, but also to a permanent and irrevocable (inextinguishable) privilege or series of privileges as to letting

${ }^{57}$ In support of these suggestions, the following utterance of an able New York judge may be noted:

"A claim for an easement must be founded upon grant, by deed or writing, or upon prescription which presupposes one, for it is a permanent interest in another's land, with a right, at all times, to enter and enjoy it; but a license is an authority to do a particular act, or a series of acts upon another's land, without possessing any estate therein. It is founded in personal confidence, and is not assignable. This distinction between a privilege or easement carrying an interest in land, and requiring a writing within the statute of frauds to support it, and a licence which may be by parol, is quite subtle, and it becomes difficult, in some of the cases, to discern a substantial difference between them.

"I shall not undertake to reconcile these various cases. It is evident the subject has been understood very differently by different judges. But in this all agree, that according to the Statute of Frauds, any permanent interest in the land itself cannot be transferred, except by writing. Much of the discrepancy may have arisen from the different ideas attached to the word licence." Savage, C. J., in Mumford $v$. Whitney (1836) 15 Wend. 380, 392.

This passage, in spite of the tendency to use language similar to that of Vaughan, C. J., in Thomas $v$. Sorrell, shows that the real contrast is that of a permanent interest as opposed to a temporary and "revocable" one, rather than that of an interest as opposed to none at all.

Compare also Chancellor Kent, in 3 Com. 452:

"Such a parol license to enjoy a beneficial privilege is not an interest in land within the Statute of Frauds."

${ }^{83}$ See ante, p. 93. 
down the surface land. Such an "irrevocable" continuing privilege (or series of privileges) would seem clearly to be an interest in land-so substantial an interest as to require a deed at common law, and a writing under Section I of the Statute of Frauds. ${ }^{58 a}$ This would seem to be true, even if the "right and privilege" in Penman v. Jones were conceded to consist merely of a continuing series of privileges; and, of course, it becomes increasingly difficult to deny that the "right and privilege" is an "interest" when we take into consideration the accompanying legal rights (claims) against interference either by the superjacent owner or by third parties.

Passing this point by, however, it is interesting to notice that the Pennsylvania court regards the "right and privilege" as irrevocable because "coupled with a grant [reservation] of the coal." Whatever plausibility this statement has at first glance because apparently fitting in with certain well-known classes of so-called "licenses coupled with grants," does it not lose its persuasive force when we notice that the supposed license would be coupled, in Penman v. Jones, not with the grant of a pozer concerning another's land as in the case of profits, or with the grant of a movable on another's land as in a case like Wood $v$. Manley, ${ }^{59}$ but with the grant of the whole mineral estate, as such, to the supposed holder of the "license?" That is, it would be a license "coupled exclusively with" the grant of the licensee's own estate. The court cites no case either to explain or to exemplify its conception of a "license coupled with a grant"; and such cases as have been observed are of a very different character.

The first important class of cases consists of those relating to profits $\grave{a}$ prendre. Thus, a profit consisting of the so-called "right" to dig for and carry away minerals involves a "grant" of an aggregate of jural relations including, inter alia, the legal powers ${ }^{60}$ of vesting ownership of the severed parts of the servient

${ }^{w_{a}}$ See Alderson, B., in Wood v. Leadbitter (1845) I3 M. \& W., at 843, 852,854 .

${ }^{30}$ (1839) II A. \& E. 34

${ }^{\infty}$ Compare the somewhat analogous legal powers of a tenant for life without impeachment for waste.

As said in Kekewich v. Marker (I85I) 3 McN. \& G. 3II, 333:

"We then find that the grantor has given the ordinary profits to the tenant for life, with exemption from waste, or a license to appropriate a portion of the inheritance, subject to the prior right and discretion of the trustees for raising portions. It was further insisted that the tenant for life is the owner of the timber, but that is quite out of the question; he has nothing but a power, though when he has felled the timber under 
land in the profit owner-legal powers, that is, to alter pro tanto the jural relations of the servient landowner and to create aggregates of jural relations concerning the (severed) movables in the owner of the profit. ${ }^{.1}$ In such grants there are also included

the power, it would become a chattel and he would be owner of it. We are now, however, discussing the relative rights as to standing timber, and the case cannot therefore be argued, or the claim to fell the timber supported, upon any existing property in the timber as owner."

Compare also McPherson v. Temiskaming Lumber Co., Ltd. (I9I3) A. C. 145, I52; and (1913) 23 YALE LAW JouRNAL 16, 42, n. 60.

${ }^{61}$ Doe v. Wood (I8I9) 2 B. \& Ald. 738; Muskett v. Hill (1839) 5 Bing. N. C. 706; see Clement v. Youngman (I86I) $40 \mathrm{~Pa}$. 34I, 344; Ryckman v. Gillis (1874) 57 N. Y. 68; and cf. Chartiers Block Coal Co. v. Mellon (1893) 152 Pa. 286, 296.

In Doe v. Wood, supra, Abbott, C. J., said:

"The purport of the granting part of this indenture, is to grant, for the term therein mentioned, a liberty, license, power, and authority, to dig, work, mine, and search for metals and minerals only, that should within that term be there found, to the use of the grantee, his partners, etc.; and it gives also further powers for the more effectual exercise of the main liberty granted . . . its words import a grant of such parts thereof only as should, upon the licence and power given to search and get, be found within the described limits, which is nothing more than the grant of a licence to search and get (irrevocable, indeed, on account of its carrying an interest) with a grant of such of the ore only as should be found and got. - . . If so, the grantee had no estate or property in the land itself, or of any particular portion thereof, or in any part of the ore, metals, or minerals, ungot therein; but he had a right of property only as to such part thereof as upon the liberties granted to him should be dug and got. That is no more than a mere right to a personal chattel, when obtained in pursuance of incorporeal privileges granted for the purpose of obtaining it. . These expressions . . can . . . have no further effort than to shew that the grantor supposed that the soil or minerals, and not a mere liberty or privilege, passed by his deed."

Profits involving wild game and fish differ in one particular. They involve legal pozers to acquire title ("qualified" or "absolute") "by reducing the game to possession." But the exercise of these powers does not affect the landowner in precisely the same way; for the latter himself does not have ordinary ownership of the game, but merely legal powers of acquiring title by reducing the game to possession,- - these powers being accompanied, of course, by various rights, privileges and immunities. Blades v. Higgs (1865) II H. L. CAS. 62I.

For profits of this character, compare Wickham v. Hawker (1840) 7 M. \& W. 62; Fitzgerald v. Firbank [1897] 2 Ch. 96; Bingham v. Salene (1887) I5 Or. 208, 212, I4 Pac. 523.

For a novel and interesting attempt to apply the idea of "a license coupled with a grant" to the case of a theatre ticket-a license to enter and remain coupled with the "grant" of a privilege (not pozver as in the case of a profit), see the dictum of Buckley, L. J., in Hurst v. Picture Theaters, Ltd. [1915] I K. B. I, 7: "Let me for a moment discuss this present case upon the footing that Wood $v$. Leadbitter stands as good law 
the privileges of physically severing or causing to be severed the various mineral portions from the corpus of the land; various rights (or claims) against interference with or disturbance of the activities and advantages connected with the exercise of such privileges and powers-rights (or claims) against third parties as well as against the grantor of the profit ${ }^{62}$ also various immunities similar to those that any owner of property ordinarily has. $^{63}$ As regards such profits, the aggregate of jural relations is not, in any ordinary case, subject to a power of "revocation" or extinguishment by the grantor. This is true of the continuing or repetitive privileges involved as well as of the other elements. Hence the frequent loose description of the situation as involving an "irrevocable license" coupled with a grant. But the term license is really used here most unfortunately, -as that term, for the sake of clearness of thought and exactness of expression, should be reserved for the "mere permission" under consideration by Chief Justice Vaughan in Thomas v. Sorrell-that is, in the first paragraph of the quotation above given. ${ }^{64}$

at this date. I am going to say presently that to my mind it does not, but suppose it does stand as good law at this date. What is the grant in this case? .... That which was granted to him was the right [privilege] to enjoy looking at a spectacle, to attend a performance from its beginning to its end. That which was called the license, the right [privilege] to go upon the premises, was only something granted to him for the purpose of enabling him to have that which had been granted to him, namely, the right [privilege] to see. He could not see the performance unless he went into the building ... So that here there was a license coupled with a grant. If so, Wood $v$. Leadbitter does not stand in the way at all. A license coupled with a grant is not revocable; Wood v. Leadbitter affirmed as much."

-

Sed qu.: was there not, in Wood v. Leadbitter an attempted grant of the privilege of seeing the races?

"Fitzgerald v. Firbank [r897] 2 Ch. 96.

See ante, p. 69, n. 8.

a To be compared with cases of profits à prendre are those referred to in Tiffany, Real Property (1903) 683:

"So, in some states, an oral sale of growing trees is insufficient to pass them as such, and is regarded as giving the vendee merely a license or permission to cut the trees, which is revocable until the trees are cut, but, after they are cut, the sale takes effect upon them in their chattel character, and the vendee then, having an interest in the trees, has an irrevocable license to enter on the land for their removal."

See, for this doctrine, Giles v. Sinonds (1860, Mass.) I5 Gray, 44I;

United Soc. v. Brooks (I888) I45 Mass. 4ro.

Tiffany's characterization of these cases seems hardly adequate, as it fails to bring out the "revocable" legal powers of acquiring title to the 
A second class of authorities involving so-called "licenses coupled with a grant" consists of cases like Wood v. Manley. ${ }^{\circ 5}$ This leading case established the rule that the sale of a movable located on the vendor's land, coupled with permission to enter on the land for the purpose of removal, results in an "irrevocable" privilege (frequently called "license") of entering on the land and removing the object purchased. It would seem clear that in this case also there are accompanying rights (or claims) against interference. It is equally clear that the total aggregate (rights, privileges, powers, and immunities) should be recognized as an interest in land, even though not within the general common law requirement of a deed or the requirement of Section I of the Statute of Frauds. Similar considerations are applicable to cases involving permission to place movables upon another's land and to remove them at some subsequent time. ${ }^{68}$

In leaving this part of the discussion, the suggestion may be ventured that an examination of the court's application of the category of license tends only to confirm the conclusion, already reached on independent grounds, that the "right and privilege" in Penman $v$. Jones should more properly have been classified as an easement appurtenant, with the necessary inference that such "right and privilege" passed with the subjacent estate, even apart from the special language about to be considered.

(2) DID THE “RIGHT AND PRIVILEGE" PASS UNDER THE LANGUAGE OF THE CONVEYANCE OF I89I, INDEPENDENTLY OF ITS BEING AN EASEMENT?

The court concedes that the interest, whatever it may be called, is freely alienable, along with the subjacent estate proper. Earlier Pennsylvania cases, already noticed in detail, leave no room for doubt as to this point. Unless, therefore, there is something peculiar about this sort of interest so as to require unusually specific terms of conveyance, it would seem that the words "all the estate, right, title, interest, benefit, property,

severed trees by exercising the "revocable" legal privileges of physically severing the trees.

The cases put by Vaughan, C. J., in the second paragraph of the quotation given in the text seem to be similar to those now under consideration. The "grant" that he refers to is, in reality, the grant of legal powers, rather than of ownership of the severed things as such.

( (1839) rr A. \& E., 34.

o Giles v. Simonds (1860, Mass.) I5 Gray, 44I ; cf. the explanation given in Browne, St. Frauds (5th ed., I895) sec. 27 ; also the similar explanation of Alderson, B., in Wood v. Leadbitter (1845) I3 M. \& W., at 853 . 
claim and demand whatsoever" together with "all and singular ... the appurtenances . . . belonging to the said property or in anywise appertaining to the same" were ample to cover the "right and privilege" of letting down the surface. Apart from absolutely specific terms, it would be difficult to find more comprehensive language. It is true that in Stilley $v . B u f f a l o \mathrm{Co}^{87}$ and in Kirzein v. Del., L. \& $W . R . R$. Co ${ }^{68}$ the terms employed were quite specific; but, as will be remembered, no reference to this point was made in either of these cases, and, instead, the court's reasoning proceeded along very broad lines as to the intentions of the original parties as indicated by their instruments of conveyance and the surrounding circumstances.

It would seem unnecessary, however, to resort to these earlier cases to show the adequacy of such inclusive generic terms as have just been quoted from the conveyance of $189 \mathrm{I}$; for does not the very case of Penman $v$. Jones afford all-sufficient authority?

(3) WAS THE COURT CONSISTENT IN HOLDING, IN SPITE OF ITS NEGATIVE ANSWER TO THE SECOND QUESTION, THAT THE LANGUAGE IN THE CONVEYANCE FROM A TO $D$ WAS SUFFICIENT TO PASS THE "RIGHT AND PRIVILEGE" TO D?

This question is clearly enough suggested by the facts of Penman v. Jones, although the limited purposes of this article do not demand an extended discussion thereof or, much less, any positive answer. The important words in the conveyance from $A$ to $D$ were, it may be recalled, "all and every the real estate or interest of any kind or nature in real estate, lands, tenements or hereditaments," etc. These words, in and of themselves, seem less comprehensive and intensive than those in the conveyance from $A$ to $C$. The court's reasons for denying natural force and effect to the words of the "A-C" conveyance and attributing such force and effect to the weaker words of the "A-D" conveyance are hardly convincing. Those reasons are given chiefly in the language already quoted from the majority opinion; and, as will be remembered, they seem to turn largely, if not entirely, on an unfortunate identification of the subjacent owner's privilege of letting down the surface with a superjacent owner's right (or claim) that the surface should not be let down. ${ }^{69}$

" (rgr2) $234 \mathrm{~Pa} .492,497$. For full consideration of this case, see ante, p. 78.

* (rgr5) $249 \mathrm{~Pa} .98$, ror. For full consideration of this case, see ante, p. 78.

See ante, p. 83 , and p. 84, n. 40. 